concentrations $<100 \mu \mathrm{g} / \mathrm{l}$ before treatment with erythropoietin.

Transferrin saturation is a good indicator of the current balance of supply and demand of plasma iron, although it is an inadequate indicator of the amount of iron stored. ${ }^{23}$ In addition, Bainton and Finch showed that once the transferrin saturation falls below $16 \%$ iron supply for erythropoiesis may be inadequate. ${ }^{+} \mathrm{O}$ ur data also suggest that, during treatment with erythropoietin, monitoring of transferrin saturation is more reliable for detecting functional iron deficiency than is monitoring of serum ferritin concentration.

We believe that functional iron deficiency will become an increasing problem as treatment with erythropoietin is used more widely unless prophylactic iron is given parenterally when indicated - that is, when transferrin saturation falls below $20 \%$. This iron supplementation should also optimise the cost effectiveness of the drug.

We thank MCP Pharmaceuticals for financial help and for supplying erythropoietin; Ann Pugh and Richard Ellis for measuring serum ferritin concentrations; and Sara Hughes and David Trevett for assaying serum iron concentrations and total iron binding capacity.

1 Eschbach JW, Egrie JC, Downing MR, Browne JK, Adamson JW. Correction of the anemia of end-stage renal disease with recombinant human erythropoietin. $N$ Engl M Med 1987:316:73-8.

2 Cavill I. Clinics in haematology. Vol 11. London: W B Saunders, 1982:259-73.

3 Hussein S, Prieto J, O'Shea M, Hoffbrand AV, Baillod RA, Moorhead JF. Serum ferritin assay and iron status in chronic renal failure and hacmodialysis Serum ferritin assay and
BrMed $\mathcal{F} 1975 ; \mathrm{i}: 546-8$.

4 Bainton DF, Finch CA. The diagnosis of iron deficiency anemia. Am 7 Med 1964;37:62-70.

(Accepted 12 April 1989)

\section{Randomised trial of two strategies offering women mobile screening for breast cancer}

\author{
E M I Williams, M P Vessey
}

Department of Community

Medicine and General

Practice, Radcliffe

Infirmary, Oxford

OX2 6HE

E M I Williams, MB, senior registrar

M P Vessey, FFCM, professor

Correspondence to: $\mathrm{Dr}$ Williams.

BrMed f 1989;299:158-9
High compliance is an important prerequisite for effective population screening.' Responses to breast cancer screening of $85 \%$ and over have been achieved in Sweden ${ }^{2}$ and The Netherlands, ${ }^{3}$ but in the United Kingdom responses have been more modest: $60 \%$ in Guildford and $72 \%$ in Edinburgh. ${ }^{+}$These responses resulted from active invitation to participate, though the precise methods used have not been reported.

We determined whether compliance would improve if a letter of invitation contained a definite appointment for screening rather than an open ended request to make an appointment.

\section{Subjects, methods, and results}

A sample of 450 women aged 45-64 was identified from the age-sex registers of two general practitioners from one practice in Aylesbury and randomly allocated to receive either a letter with an appointment (group 1) or an open ended letter of invitation (group 2) for breast cancer screening. The letters were signed by the general practitioner and had, as far as possible, identical texts. At the screening office alternate appointments were allocated to the two groups.

Women in group 1 were asked to contact the screening service to cancel or alter appointments but not to confirm them. Women in group 2 were invited to return a form indicating convenient times; an appointment was then sent. Non-responders were sent a reminder after three weeks. Non-attenders from both groups were sent another appointment.

Both groups were comparable for age, previous screening (56 (30\%) and $69(34 \%)$ respectively had been screened before as volunteers), and where they lived.

Three invitations were accidentally sent to men. These and women who had moved, were duplicated on the register, and were known to have been screened recently were excluded. Nine women were inadvertently sent invitations instead of appointments, and one was sent an appointment instead of an invitation; they were also excluded. This left 188 women in group 1 and 204 women in group 2.

The table gives the main results. Women in group 1 had a significantly higher rate of response than women in group 2. Significant differences remained when the 10 women inadvertently sent the wrong letter were included according to both the received and the intended strategies. Compliance was improved in group 1 after every contact, though individual differences were not significant, and was higher than that in group 2 for all age groups, for previously screened women, and for previously unscreened women $(\mathrm{p}<0 \cdot 05)$.

Response to invitation to breast cancer screening by appointment (group 1) or open ended invitation (group 2). Figures are numbers (percentages) unless stated otherwise

\begin{tabular}{lcc}
\hline & $\begin{array}{c}\text { Group 1 } \\
(\mathbf{n}=188)\end{array}$ & $\begin{array}{c}\text { Group 2 } \\
(\mathbf{n}=204)\end{array}$ \\
\hline Mean age (years) & $55 \cdot 4$ & $56 \cdot 1$ \\
Screened at: & & \\
$\quad$ First contact & $131(69 \cdot 7)$ & $131(64 \cdot 2)$ \\
Second contact & $26^{\star}(13 \cdot 8)$ & $19 \dagger(9 \cdot 3)$ \\
All other contacts & $5 \ddagger(2 \cdot 7)$ & $4 \rrbracket(2 \cdot 0)$ \\
\hline Total & $162 \|(86 \cdot 2)$ & $154(75 \cdot 5)$
\end{tabular}

*After cancellation (13) or non-attendance (13).

†After reminder.

¥After both cancellation and non-attendance.

SAfter cancellation (2) or non-attendance (2)

Continuity adjusted $\gamma^{\prime}=6 \cdot 47 ; \mathrm{df}=1 ; \mathrm{p}=0.01$

From a total of 273 appointments issued to women in group 1, $45(24 \%)$ were unused through non-attendance; $32(17 \%)$ became available for reuse $-15(80 \%)$ after cancellation and $17(90 \%)$ after refusal or when letters were returned unopened. Unfilled and cancelled appointments in group 2 each accounted for under $2 \%$ (4) of the total.

\section{Comment}

This study shows that including an appointment in the invitation significantly enhances compliance with screening compared with an open ended invitation, confirming earlier findings reported for cervical screening. ${ }^{5}$ The improvement persisted across all contacts and age bands and remained regardless of screening history. This improvement may have arisen because a definite appointment may place more onus on women to attend.

The postage for group 1 cost about half that for group 2. Also, clerical staff reported that they found the appointment strategy more straightforward than the invitation strategy, though the work entailed was different. Non-responders are never given appointments with a system of open ended invitations. With pre-allocated appointments several remain vacant unless overbooking is allowed. Overbooking of preallocated appointments, however, remains to be tried, 
particularly in a mobile service in which flexibility is limited. Furthermore, its use may affect acceptability.

In conclusion, higher compliance is achievable with preallocated appointments, though the method described requires further evaluation especially for use in mobile screening.

We thank the staff of the Aylesbury Vale breast screening service for their help and Drs E Rose and M Orton for allowing us to study patients under their care.
1 Working Party on Breast Cancer Screening. Report to the health ministers of England, Wales, Scotland and Northern Ireland. London: HMSO, 1987. (Forrest report.)

2 Tabar L, Fagerberg CJG, Gad A, et al. Reduction in mortality from breast cancer after mass screening with mammography. Lancet 1985;i:829-32.

3 Verbeek ALM, Hendriks JNCL, Holland R, Mravunac M, Sturmans F, Day NE. Reduction in breast cancer mortality through mass screening with modern mammography, Lancet 1984; $;: 1222-4$.

4 United Kingdom Trial of the Early Detection of Breast Cancer Group. Firs results on mortality reduction in the UK trial of the early detection of breast results on mortality reduction in
cancer. Lancet 1988;ii:411-6.

5 Wilson A, Leeming A. Cervical cytology: a comparison of two call systems. Br Med f 1987;295:181-2.

(Accepted 26 April 1989)

\section{Reversible toxicity in poisoning with colloidal bismuth subcitrate}

\author{
Mark Hudson, N Ashley G Mowat
}

Gastrointestinal Research

Unit, Aberdeen Royal Infirmary, Aberdeen AB9 2ZB

Mark Hudson, MRCP, registrar

N Ashley G Mowat, FRCP, consultant physician

Correspondence and requests for reprints to: Dr Mowat.

BrMed f 1989;299:159

Encephalopathy after long term treatment with some bismuth salts has been widely reported, but toxicity from colloidal bismuth has not been recognised. We report the results of an overdose of colloidal bismuth.

\section{Case report}

A 27 year old man was admitted four hours after an overdose of $100 \mathrm{De}-\mathrm{Nol}$ (colloidal bismuth) tablets $(12 \mathrm{~g})$, paracetamol (blood concentration $30 \mathrm{mg} / \mathrm{l}$ ), and alcohol (blood concentration $162 \mathrm{mg} / \mathrm{l}$ ). Blood bismuth concentration was not measured. The next day he felt well and was discharged. Ten days later he was admitted to our unit complaining of anorexia, nausea, vomiting, general malaise, weakness of his legs, blurring of vision, thirst, and poor urinary output. $\mathrm{He}$ was dehydrated and unwell but had no fever or tachycardia. He had proximal leg muscle weakness with hyperreflexia and ankle clonus. His plantar reflexes, all senses, and both fundi were normal. $\mathrm{He}$ was lucid with no signs of encephalopathy.

Biochemical investigations yielded the following results: serum sodium $130 \mathrm{mmol} / \mathrm{l}$, serum potassium $4.3 \mathrm{mmol} / \mathrm{l}$, plasma bicarbonate $30 \mathrm{mmol} / \mathrm{l}$, plasma urea $69.9 \mathrm{mmol} / \mathrm{l}$, and plasma creatinine $2804 \mu \mathrm{mol} / \mathrm{l}$. Bismuth was detectable in his blood $(260 \mu \mathrm{g} / \mathrm{l})$, urine $(120 \mu \mathrm{g} / \mathrm{l})$, and stools $(26.9 \mathrm{mg} / \mathrm{g})$ but not in cerebrospinal fluid. Standard tests of liver function yielded normal results. An abdominal $x$ ray film showed opacification of the colon by ingested bismuth. An electroencephalogram showed non-specific slow wave changes over both hemispheres.

Renal failure and neurotoxicity induced by bismuth were diagnosed. After initial purgation with magnesium sulphate and rehydration with $0.9 \%$ saline haemodialysis was started. Five days later renal function had returned to normal and neurological signs resolved. The patient felt well. The table gives the blood urea, creatinine, and bismuth concentrations 96 days after ingestion.

\section{Comment}

Toxicity after ingestion of bismuth subgallate, subcitrate, and subsalicylate may result in tremors, confusion, myoclonus, ${ }^{2}$ encephalopathy with characteristic electroencephalographic changes, and fits. The mechanisms are not clear. Although colloidal bismuth subcitrate is much less easily absorbed, small quantities of it do enter the blood of animals
Blood urea, creatinine, and bismuth concentrations during 96 days after overdose with colloidal bismuth subcitrate

\begin{tabular}{|c|c|c|c|c|}
\hline $\begin{array}{c}\text { Days } \\
\text { after } \\
\text { ingestion }\end{array}$ & $\begin{array}{l}\text { Before } \\
\text { or after } \\
\text { dialysis }\end{array}$ & $\begin{array}{c}\text { Urea } \\
(\mathrm{mmol} / \mathrm{l})\end{array}$ & $\begin{array}{c}\text { Creatinine } \\
(\mu \mathrm{mol} / \mathrm{l})\end{array}$ & $\underset{(\mu \mathrm{g} / \mathrm{l})}{\begin{array}{c}\text { Blood } \\
\text { bismuth }\end{array}}$ \\
\hline 0 & \multirow{4}{*}{$\begin{array}{l}\text { Before } \\
\text { After }\end{array}$} & $<2.5$ & 97 & \\
\hline 11 & & $69 \cdot 9$ & 2804 & 260 \\
\hline 12 & & $69 \cdot 4$ & 2952 & 185 \\
\hline 12 & & $45 \cdot 7$ & 1693 & 84 \\
\hline 13 & $\left\{\begin{array}{l}\text { Before } \\
\text { After }\end{array}\right.$ & $\begin{array}{l}46 \cdot 3 \\
27 \cdot 8\end{array}$ & $\begin{array}{l}1938 \\
1165\end{array}$ & $\begin{array}{l}165 \\
160\end{array}$ \\
\hline \multirow{2}{*}{14} & \multirow{2}{*}{$\begin{array}{l}\text { Before } \\
\text { After }\end{array}$} & & & 200 \\
\hline & & $16 \cdot 7$ & 760 & 160 \\
\hline \multirow{2}{*}{15} & \multirow{2}{*}{$\begin{array}{l}\text { Before } \\
\text { After }\end{array}$} & & & 165 \\
\hline & & $9 \cdot 4$ & 460 & 150 \\
\hline \multirow{2}{*}{16} & \multirow{5}{*}{$\begin{array}{l}\text { Before } \\
\text { After }\end{array}$} & $10 \cdot 3$ & 475 & \\
\hline & & $<2 \cdot 5$ & 140 & 150 \\
\hline 20 & & $7 \cdot 7$ & 185 & 200 \\
\hline 60 & & 3.8 & 98 & 19 \\
\hline 96 & & $2 \cdot 7$ & 88 & 8 \\
\hline
\end{tabular}

^Measured by atomic absorption spectrometry.

and humans, with tissue binding in animal kidneys especially but also in the spleen, liver, brain, heart, and skeletal muscle. ${ }^{34}$ Bismuth may cause decreased glomerular filtration, reduced renal blood flow, and defects of proximal tubular reabsorption. ${ }^{5}$ In rats given high doses colloidal bismuth crosses the blood-brain barrier.

The absence of bismuth in cerebrospinal fluid may explain why the patient was not encephalopathic, and his transient neurological signs may have reflected his uraemia, itself a result of bismuth toxicity. The initial fall in blood bismuth concentration occurred after simple rehydration and purging. Reductions in blood bismuth concentration after haemodialysis were transient, the bismuth presumably being re-established from tissue stores but never reaching symptomatic concentrations.

The optimal treatment of overdose with colloidal bismuth is unknown. Within the first few hours absorption should be minimised by early hydration, gastric lavage (refused by this patient), and purging, even if the patient presents late as bismuth may well be absorbed from the colon. Chelating agents, such as penicillamine, may be effective in the early stages before tissue binding has occurred. Haemodialysis may be necessary, but whether this hastens tissue clearance of bismuth is uncertain. Even after large overdoses, as in this patient, the prognosis is good.

1 Rooney RC. Determination of bismuth in blood and urine. Analyst 1976;101 $749-52$.

Buge A, Rancurel G, Dechy H. Encéphalopathies bismuthiques: données étiologiques et pharmacologiques. Nouvelle Presse Medicale 1978;7:3531-4.

Buge A, Supino-Viterbo V, Rancurel G, Pontes C. Epileptic phenomena in bismuth toxic encephalopathy. I Neurol Neurosurg Psychiatry 1981;44:62-7. Lee SP, Lim TH, Pylbus J, Clarke AC. Tissue distribution of orally Lee SP, Lim TH, Pylbus J, Clarke AC. Tissue distribution of orally
administered bismuth in the rat. Clin Exp Pharmacol Physiol 1980;7:319-24. 5 Czerwinski AW, Ginn HE. Bismuth nephrotoxicity. Am J Med 1964;37:969-75. (Accepted 20 April 1989) 